5. Burchell, John. Public library research: a perspective from the British Library. Paper to the Kenilworth seminar, February 1994 (circulated to participants).

6. McKee, Bob. A public librarian's view.In Harris, C. ed. Research policy in librarianship and information science. London: Taylor Graham, 1991.

7. Huse, Roy. Public Library Development Incentive Scheme 1988-92: a strategic evaluation. London: HMSO, 1993. (Distributed by BLRDD).

8. Moore, Nick. Public library research: a study of the development and current state of public library research in Great Britain. London: The British Library, 1978 (BLRDD Report 5419).

9. Moore, Nick. Research and practice: 21 years of library research in the UK. London: The British Library, 1987. (Library and Information Research Report 55).

10. Stewart, Linda. Public library research: a review of UK investigation between 1978 and 1982. Loughborough: CLAIM, 1984. (CLAIM Reports 35).

\title{
A framework of the transferable skills of information professionals
}

\author{
JANE FARMER \\ FIONA CAMPBELL \\ KAY WILSON \\ DOROTHY WILLIAMS
}

School of Information and Media

The Robert Gordon University

\section{Background}

This project originates from the comments of information professionals attending two seminars run by the School of Information and Media on the subject of career development and planning. The first seminar concerned a group of Scottish health sciences librarians. Much of this seminar concentrated on working through the Library Association's Framework for continuing profes$\underline{\text { sional development }}^{(1)}$ with participants, but there were various opportunities for brainstorming and discussion about the opportunities and barriers to career development for health sciences librarians. Participants were unanimous and clear about what could most usefully be done to assist them with their career development. The most desirable aspect they wanted was recognition for their skills, training and experience. They wanted to feel there were pathways for their careers to develop along. They asked that their skills and competencies should be analyzed and presented within a framework document that could be shown to management. This would provide atool which could be used in appraisal situations, when applying for jobs, regradings and so on. This would help information professionals to analyze their own skills and suggest how they these could be built upon in order to facilitate career development or enhancement.

A few months later another career planning seminar was carried out with librarians from the independent schools sector. Despite working in quite different types of organization, not surprisingly, their comments and requirements were very similar. So although this project is 
specifically looking at the transferable skills of two groups of special librarians (in the health services and oil industry sectors), it is felt that results will be reasonably generalizable.

The experience of the career development and planning seminars suggested that a project that aimed to identify a framework of the transferable skills of information professionals, was topical and recognized by a wide range of practitioners as being needed. The British Library have acknowledged this need by funding a project for 15 months from January 1996. The following article outlines some of the background and the methodology to be used in the project.

\section{A longstanding problem}

A preliminary analysis of the literature showed that commentators and researchers within the profession had been discussing issues related to the problem of barriers to career development for some time. In the mid 1980s the American Library Association carried out a survey of its members, looking at career development and job satisfaction. One of the findings noted by researchers Bernstein and Leach ${ }^{(2)}$ from this study was that:

"career satisfaction for substantial numbers of

librarians... will have to take place in existing jobs.

They have reached what is termed a "a plateaued condition"."

The "plateaued condition" referred to large numbers of information professionals who had reached a stage in their career where there were no obvious routes for advancement within their own profession.

It is not difficult to find examples of plateaued professionals within the UK librarianship sector of the 1990s. The job market is tight, with an overarching ethos of job insecurity. In a society whose message is work better and harder, there are many able people frustrated by lack of opportunity. In addition, the longer a professional stays in the same job, the more highly skilled and specialized for that particular environment they become. Ironically, this very specialism is likely to present a barrier which prevents the professional entering other fields of work. Research looking at Scottish health sciences librarians showed that $47 \%$ had worked in health sciences for more than 10 years ${ }^{(3)}$. As Koenig ${ }^{(4)}$ highlights

"there is a substantial degree of vertical stratification

within the library field - public, academic, corporate and

school librarianship are almost regarded as separate fields".

He goes on to add that this phenomenon is "not to the benefit of the field". This stratification makes it difficult for librarians to move from one sector to another, thus preventing crossfertilisation of ideas between library sectors and preventing career development or advancement.

The librarian working in a specialized environment over a period of time often begins to have a lot more in common with the other employees in that environment than they do with the rest of their professional group. Librarians in the health service, for example, develop a high level of knowledge of management and medical jargon, and get to know and work with key organizational figures and concepts. Yet, despite this, they experience professional isolation and their opportunities for moving into other fields of work within the same environment would seem to be limited. 
A survey carried out in $1992^{(5)}$ showed that NHS managers perceived librarians' skills as lying primarily in the traditional library areas - "cat/class," stock management and online searching. While around two thirds of managers sampled felt that librarians could move into information management and information technology functions, about half of this group felt they would need extra training in order to do this. Although little formal research has been carried out, anecdotal evidence points to a similar picture for librarians in other sectors.

\section{Transferable skills}

It is generally recognized within the information profession that members have a range of generic

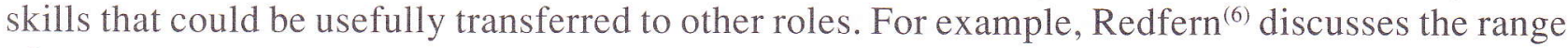
of managerial and interpersonal skills that librarians possess. Others highlight information technology, management skills, communication skills, etc. In addition research has shown ${ }^{(7)}$ that many health service librarians are engaged in the contracting process, setting quality standards, budgeting, business planning and so on. Likewise few industrial librarians are restricted to the management of traditional collections and many are involved in information management and quality monitoring.

A number of current initiatives attempt to provide skills frameworks for other professions which can be used as checklists or keystones to further professional development. Initiatives relevant for the sector being examined here include the Management Charter Initiative, ${ }^{(8)}$ S/NVQs, the NHS Information Management and Technology Strategy's Statement of Recognition ${ }^{(9)}$ and Checklist questionnaire for managers ${ }^{(10)}$. Such frameworks will form a useful background for the skills analysis tools to be devised for information professionals in this project. Information about potential courses which could be used to top up librarian's skills will also be collected and analyzed.

In 1992 the Library Association produced its Framework for Continuing Professional Develop$\underline{\text { ment }}^{(11)}$, a do-it-yourself pack which encouraged librarians to think about their professional and personal development in partnership with their employers. This pack served to highlight the need for and interest in continuing education. However, it also served to show to many, particularly special librarians, how confusing it is to identify what areas for career progression they could reasonably look to, without the further consideration of how to go about getting there.

One way of bringing analysis of transferable skills to the fore would seem to be via the appraisal process (for organizations which have a formal appraisal strategy). This would seem to provide a perfect opportunity to highlight generic skills which could be transferred and investigate ways to develop or accredit these skills through a variety of strategies. These might include formal mentoring strategies, secondments, projects, action learning or continuing education through distance/open learning or attendance at short courses. At present, these types of opportunity would seem to be lacking. Many librarians are not part of a formal organizational appraisal strategy and, even if they are, many express frustration at the difficulties of convincing their managers (nonlibrarians) that what they do is worthwhile and that they do have transferable skills. The current employment climate is also a major hindrance to encouraging staff to press for better development opportunities. In both sectors under examination in this project, perhaps particularly the oil industry, there is a great deal of insecurity among professionals due to threats of organizational review, downsizing, outsourcing, mergers and so on. Therefore, the marketing of the ethos of this project will have to be handled with great tact and diplomacy! 


\section{Methodology}

The general approach currently planned in the skills analysis stage of the project is the "learning pairs" technique used by Tremblay and Wall ${ }^{(12)}$ at the University of Birmingham to help managers in different types of health service organizations understand each other's roles. This is basically a mentoring technique which will involve linking the participating information professional(A) with someone currently in a parallel or more senior post in another profession(B). The mentoring professional B will be doing a job which A might reasonably be able to move into - for example - in management, IT, PR, etc. As and Bs will work through a schedule of meetings together, some facilitated by the project researcher. The aims of the meetings will be for As and Bs to analyze each other's jobs in terms of the skills, competencies and personal attributes required to carry them out effectively. As and Bs will also analyze their own and each other's personal skills. During the process they will gain a greater appreciation of each other's roles and skills. Participating information professionals will also be encouraged to meet together as a support group to discuss their jobs and skills.

The project staff will play a highly supportive, facilitating role throughout the project. Stage one will involve identifying a group of 30 or more participants. These will be information professionals in posts in the health service or oil industry sector who feel they would like to develop their careers, but are not sure what to do about it. Having done this, at Stage two the project team will construct diagnostic tools to enable participants to analyze the type of job they would like to move into.

Stage three will involve finding learning partners or mentors for the participants. This is anticipated as being potentially quite difficult. The concept of the project will need to be marketed very carefully - emphasizing the growth of skills and understanding on the part of mentor and mentored - if mentors are to be found who are willing to give up their time to assist. Even so, it is expected that much liaison and discussion will have to take place with personnel and training officers in various organizations to facilitate the success of the project.

Stage four will involve the participants - As and Bs - working through a series of meetings together in each other's organizations as well as on neutral territory. Sometimes these meetings will be facilitated by the project researcher. The meetings will involve:

- $\quad \mathrm{A}$ and $\mathrm{B}$ getting to know each other

- $\quad \mathrm{A}$ and B discussing each other's organizations and roles

- $\quad \mathrm{A}$ and $\mathrm{B}$ observing each other at work and discussing this

- $\quad A$ and B analyzing themselves and their jobs in terms of skills, training and education required, experience required, competencies, personal attributes, organization's expectations of them.

- A and B analyzing each other's jobs in terms of the factors outlined above.

The project will devise a set of tools to help the participants carry out analyses. Although this will primarily involve work on the part of participants, it is also anticipated that they will learn a lot from the experience and actually have some fun in the process.

At Stage five a project report will be produced which will outline the framework of transferable skills identified. The report will also evaluate the feasibility of such a mentoring project. As well 
as the report, a pack will be produced which will be designed to help practitioners make the most of their generic skills.

\section{A framework of transferable skills}

The main thrust of this project, then, is to assist information professionals in their career development. This may be within existing posts or to expand their opportunities for career advancement into a wider range of potential roles such as general management, information technology, public relations, quality assurance, etc. In order to do this the primary deliverable will encompass a broad framework of the generic skills/competencies/attributes discovered within the group under study. It is proposed that this framework will serve to empower librarians to engage in various strategies to stimulate their own career development. For example, it might be used to market professionals skills within their organization. It might be used to pursue development opportunities through appraisal such as formal mentoring, secondments, and so on. A further deliverable devised as part of the process of the project will be a diagnostic tool for allowing librarians to analyze their own skills in more depth (in relation to the generic framework). This is intended to assist professionals to identify which areas they could usefully top up by means of further education or comparable learning strategies. This would allow librarians to work towards gaining further qualifications which employers would see as attractive outside traditional librarianship jobs. A summary of the results of the project, the framework of generic skills and the diagnostic skills analysis tools will be presented as a concise and accessible pack for use by

individuals. It is anticipated that the work of this project will be of interest to Schools of Librarianship and Information Science (perhaps in partnership with other disciplines, for example Business Management) who might wish to use the findings as a basis for developing distance learning which would build on and enhance librarians' transferable skills.

For further information, please contact:

Fiona Campbell

School of Information \& Media

The Robert Gordon University

352 King Street

ABERDEEN

AB9 2TQ
Tel: 01224262957

Fax: 01224262969

E-mail: f.campbell@rgu.ac.uk

\section{References}

1. The Library Association. Framework for Continuing Professional Development. London: LA, 1992.

2. Bernstein, E. and Leach, J. Plateau: in career development sampling, librarians see advancement as a problem. American Libraries, March 1985, pp.178-180.

3. Farmer, J. Health sciences librarians in Scotland: changes, issues and perceptions: results of a questionnaire survey. Aberdeen: Robert Gordon University, 1994.

4. Koenig, M.E.D. The transfer of library skills to nonlibrary contexts. pp.1-23. In: Godden, I.P. ed. Advances in librarianship, Vol.15. San Diego, Ca: Academic Press, 1991.

5. Farmer, J. Small sample survey of NHS managers' perceptions of the career development of health service librarians. (Unpublished) 1992. 
6. Redfern, M. Grow your own. Information and library manager, 9(4), 1990, pp.4-6.

7. Op. cit. 3

8. Management Charter Initiative. London: Department of Employment, 1995.

9. NHS Training Division and ASSIST Statement of Recognition. Bristol: NHSTD, 1995.

10. Details about the Checkpoint questionnaire for managers can be obtained from: IM\&T Programme Team, NHS Training Division, St. Bartholomews Court, 18 Christmas Street, Bristol, BS1 5BT.

11. Op. cit. 1

12. Tremblay, M. and Wall, A. Chief Executives learning together: a report for the NHS Training Directorate. Birmingham: University of Birmingham Health Services Management Centre, 1994.

The following two authors, Victoria Manglano Bosch and Liz Mackie were winners respectively, of the 1995 LIRG Postgraduate Student Prize and the Undergraduate Student Prize.

\title{
CD-ROM user interface evaluation: the appropriateness of GUIs
}

\author{
VICTORIA MANGLANO BOSCH, \\ Department of Information Science, \\ City University (London)
}

\section{Introduction}

The study's general objective was to assess the appropriateness of Graphical User Interfaces (GUI) for CD-ROM applications and examine to what extent a GUI based on Windows could facilitate the ease of use of these applications. A full account of the study is reported elsewhere ${ }^{(1)}$.

The literature review identified three main problematic areas in relation to the acceptance of CDROMs: contradictory perceptions about CD-ROMs, standardization, and the need for evaluation of interfaces.

Contradictory perceptions about CD-ROMs from publishers, users and informatimn professionals: the need for end user training.

Although publishers define CD-ROMs as 'user-friendly' and particularly suited to end users, and users are reported to be extremely attracted to and satisfied with CD-ROM products, information professionals involved in the management of CD-ROM services realized that end user searching is problematic. Studies investigating the searching behaviour of end-users have indicated the difficulties naive users encounter using CD-ROMs and the inefficiency of their search techniques 